\title{
Innovativeness in Macedonian Companies: Evidence from the Community Innovation Survey
}

\author{
Radmil POLENAKOVIK, Ivana STANKOVSKA, Bojan JOVANOVSKI, Valentina GECEVSKA, Dragan SUTEVSKI, Trajce VELKOVSKI
}

\begin{abstract}
The importance of innovations for development of knowledge-based economies is widely acknowledged. However, certain challenges for researching the innovativeness in post-socialist economies still exist. We analyse the most influential drivers for innovativeness in Macedonian enterprises. Based on the extended literature review and the firm-level dataset collected by the CIS 2012 (Community Innovation Survey 2012), the conceptual model for identifying the factors that drive innovation was developed and tested with standard multiple regression. The findings confirm that firm innovativeness could be improved by extending the number of collaborators and sources for information and knowledge. Also, further investments in research and development for innovation positively impact the variety of innovation activities in companies. In addition to the theoretical and practical implications, this study is significant because the proposed method could be adjusted and applied in many countries where CIS research is conducted.
\end{abstract}

Keywords: collaboration; Community Innovation Survey; information sources; innovativeness; Macedonia

\section{INTRODUCTION}

In recent years, innovations are recognized as the main driving force in knowledge-based economies. Increasing attention has been paid to the countries with emerging economies that undertake strategic actions to transit to innovation-led societies. Such actions are: setting up national innovation systems, strategic policy documents for enhancing the inter-sector collaboration, as well as numerous initiatives for improving the roles of each of the main spheres of the society: highereducational institutions, industry and government.

Many former socialist countries, such as Macedonia, resemble the state model of the triple helix, where the state has a governing role in the collaboration between the three main spheres of the society $[1,2]$. Therefore, when researching the social processes, such as the development of the innovations in companies, it is crucial for the specific socio-economic conditions to be taken into account. This is also supported by the conclusion that successful commercialization of a new product depends not only on its own capabilities, but also on a wide range of factors in its broader national context [3], which indicates that the wide innovation literature tailored on the cases from the developed countries could not be applied without major adjustments to the cases of the developing countries. Among the major concerns in Macedonia is the poor labour market performance due to high unemployment rates and poor-economic growth during the transition [4]. The innovations are also potential source for extending the current product portfolio for existing businesses and opening new businesses, which are sources for new employments, and they as well have a central role in the long-term survival of the organizations [5]. The capacity of the companies to innovate is among the most important factors that have impact on business performance [6]. Chesbrough suggests that many innovative companies have shifted to an open innovation model, using a wide range of external sources and factors in order to achieve and sustain innovation [7]. Macedonia has worked on the establishment of national innovation ecosystem, however, despite the great importance of innovations for addressing these major challenges, the micro-level factors that influence the innovation in enterprises are under-researched and more thorough analysis has yet to come.

The idea that the innovations, especially in high-tech industry are considered a vehicle toward transforming the economies to most competitive and dynamic knowledgebased ones, influenced the EU (European Union) to establish an instrument for comparative assessment of the innovation performance of the member states, called IUS (Innovation Union Scoreboard). In the same time, the framework conditions, cultural preferences and political priorities vary greatly among different counties. Since 2011 Macedonia has become a country that is part of this report. The main pillar of this research is a company survey, which for the period 2010-2012 was conducted in 1130 Macedonian companies. Apart from the measured indicators that are a base for benchmarking, monitoring and adjusting the innovation polices in the member states, there has not been common statistical methodology proposed for more complex analysis of the collected data samples. This paper proposes a conceptual model for investigating the main factors that significantly influence the development of innovations in Macedonian industrial sector by statistical analysis of the CIS data sample, in light of the specific national socio-economic context.

This research is important for several reasons. The theoretical contribution of the results is very valuable for the researchers investigating the innovation in developing economies, due to the scarce available literature. The findings have practical implications for the managers in the companies in planning the strategic steps for becoming more innovative, which is the key precondition for success. The Macedonian government needs to understand the dynamics of innovations and the factors that determine the innovative activities in the industrial sector in order to develop effective policy measures for enhancing the overall economic development.

\section{LITERATURE REVIEW AND HYPOTHESES DEVELOPMENT}

Innovation refers to all scientific, technological, organizational, financial and commercial activities which 
lead to, or are intended to lead to the implementation of technologically new or improved products or services.

Measuring the level of innovativeness of one company is not unambiguously defined in the literature. Product or service innovativeness is often related to the level of improvement of that product or service, which is problematic because product innovativeness does not necessarily result in enhanced product advantage. Moreover, the misrepresentation of the common innovativeness construct, regardless of the dimension level: macro (industry-level) or micro (firm-level), pervades the lack of consistency in the analysis and reporting of the product innovativeness [8].

Firm innovativeness refers to firm receptivity and willingness to adopt new ideas that lead to the development and launch of new products. Subramanian concludes that the innovativeness of the firm is perceived differently depending on the researching approach: for example, innovation diffusion research studies have used the time of innovation adoption as a measure of innovativeness of a firm, while other studies have assessed innovativeness on the basis of number of innovation adoptions [9]. So, the firm that adopts new product or process is considered to be innovative, while the innovativeness is determined by the number of innovations adopted by firms. However, for an organization to be considered as truly innovative it should exhibit innovative behaviour consistently over time, which results in a multidimensional measure of innovativeness, consisted of: number of innovation adoptions, time of innovation adoptions and consistency of time of innovation adoptions [9]. Moreover, innovative firms should adopt different types of innovation activities pertaining to all aspects of the organization [6]. In general, the diversity is related to increase in knowledge spillovers and innovation [10]. As presented in the innovation literature, there are various relations among different types of innovation activities. Many scholars have shown that different types of innovation activities influence and often complement each other [11]. Therefore, on the basis of these arguments the aim of this study is determining the factors that influence the companies to adopt different types of innovation activities. The diversification of the innovation activities is the output variable for this research.

\subsection{Setting the Hypotheses}

Previous literature has tried to identify the factors that drive innovation in the companies. This section reviews the most important publications and selects some of these factors that are of interest for the Macedonian context and that could be derived from CIS survey. Based on the selected factors, five research hypotheses are proposed.

Earlier studies researching innovations and their effect on company performance reported a positive relationship [12]. Furthermore, some of these studies used $\mathrm{R} \& \mathrm{D}$ (research and development) expenditure as principle measure of innovation, which is criticized in the later literature. In particular, R\&D expenditure could be correlated to certain innovation types, such as to product innovation, as shown for the manufacturing companies from Netherlands [13]. As stated in the Oslo Manual, the measures of innovation input, although related to technical change, are not direct measures for innovation output. Even though the innovation costs and expenses are one of the key factors for innovation activities, the expenditure approach to innovation might be misleading due to the open innovation principle, where the costs for $\mathrm{R} \& \mathrm{D}$ are often covered by university, research institution or external agency $[7,12]$. Eventually, the fact that except investments in innovation activities, the collaboration due to open innovation also leads to innovation outputs inspired us to examine both factors. Therefore, in this research we investigate the effects of innovation costs and expenses and the collaboration with different groups of actors from the innovation ecosystem for the diversification of the innovation activities in companies. These arguments lead to the following hypotheses.

Hypothesis 1: The innovation costs and expenses in a firm have a positive effect on the diversification of innovation activities.

Hypothesis 2: The diversification of the collaboration for innovation in a firm has a positive effect on the diversification of innovation activities.

One of the key activities for the development of innovation is supplying with information and knowledge for the research and development in the company. The modern technologies have significantly improved the access to information. In the network era, there are many online and offline ways to obtain information. All of these network structures stack one complex social network [14]. Applying knowledge from external sources expands firm's knowledge base and provides access to new ideas for generation of new products and technology [15]. The literature on decentralization of innovation activities differentiates between two perspectives in relation to their location: the first one emphasizes the benefits of multiple R\&D locations and derives from the knowledge-based view of the firm, while the second emphasizes the cost of decentralized innovation activity and derives from organizational economics [16]. Specialized local knowledge useful in innovation may come from many different sources, including universities, research institutes, suppliers, customers and competitors [17]. Firms that use multiple R\&D locations will be able to access greater number of knowledge sources, which in turn improves the likelihood of innovation success, but also the resulting set of innovations should span a wider range of applications as well [17]. Argyres and Silverman concluded that firms with more centralized R\&D activity will search more widely outside of their organizational boundaries for information relevant to innovation, and the resulting innovations will have a wider range of applications [16]. From these claims, it can be expected that wider range of information sources used results in greater diversification of the innovation activities. Similarly, the knowledge-based view relates the multiple R\&D locations to the access to a larger number of different knowledge sources outside of the organization, which influences the innovation output.

Although some studies have found a correlation between knowledge sourcing, multilocation of R\&D and innovation output [17], a direct link between the sources for information and knowledge and the innovation activities in the companies is still missing and should be 
examined. Hence, on the basis of the above arguments, the following hypothesis is proposed.

Hypothesis 3: The diversification of the information sources in a firm has a positive effect on the diversification of innovation activities.

Within the innovation policy in most of the developed countries, public funding for corporate innovation activities is a significant instrument that provides incentives for boosting the innovation in companies [18]. There is evidence from different countries that the programs providing public subsidization of the private sector help not only in addressing the financial constraints, but also in raising new funds. For example, the firms from United States that were awardees of the Small Business Innovation Research program, grew significantly faster and were more likely to attract venture financing [19]. Also, governmental funding helps innovation and growth of Finish SMEs in industries that are dependent on external finance [20]. In addition to the support for innovation activities by reducing the financial constraints, public funding also helps in increasing the private innovation effort [21] and leveraging additional resources for innovation. David et al. reviewed the literature on effectiveness of public funding for R\&D and innovation and reported conflicting results [22]. Many of the reviewed studies have found that public funding has positive effects for $R \& D$ and innovation [23, 24], while few of them have found insignificant or negative effects [25]. Furthermore, public funding for innovation reduces the probability of exit of a firm [26]. Hall acknowledged that the effectiveness of public funding, such as government incubators, seed funding, loan guarantees and other similar polices, deserves further investigation, especially in a cross-country study in order for the institutional factors that may influence the outcomes to be determined [27]. Therefore, it is of a great interest the role of public funding for various innovation activities to be assessed, which is summed up in the following hypothesis.

Hypothesis 4: A higher use of public funding for innovations by a firm has a positive effect on the diversification of innovation activities.

The governments from many countries provide different programs for encouraging the graduates to work in industries, so that they could transfer technology and knowledge gained at universities to firms [28]. These programs are mainly intended to assist firms in boosting the innovative activities and commercializing innovations. The assumption that innovations could result from transferring the knowledge and information from universities to firms is reflected in creation of university research centres and centres of excellence clustered near many advanced universities [29]. A recent example where universities are key source to radical innovations is biotechnology [30]. In addition, modern technologies facilitating e-learning create a possibility of distance learning cooperation [31]. Highly-educated employees enable firms to access higher level skills. These skills and capabilities determine the innovation productivity because they influence the ability of the firm to utilize technological and scientific knowledge [32]. Higher educational institutions and other providers of trainings are often more familiar with the external environment and might introduce the companies to certain aspects of it. A study researching the innovation practices in Netherlands finds out that innovation in service industries is related to input from highly-educated human resources [13].

As a result, we expect a greater share of highlyeducated staff in a firm to drive greater variety of innovation activities, which is claimed in the following hypothesis.

Hypothesis 5: The greater percentage of the highlyeducated staff in a firm has a positive effect on the diversification of innovation activities.

\subsection{Development of the Conceptual Model}

Based on the literature review and the selected factors for innovativeness, we generated five hypotheses representing the interrelationships among each of the factors: innovation costs and expenses, public funding, diversification of the collaboration for innovation activities, highly-educated staff and diversification of information sources on one side, and the diversification of innovative activities in the companies, on another. These hypotheses create the conceptual model that summarizes our research objectives (Fig. 1).

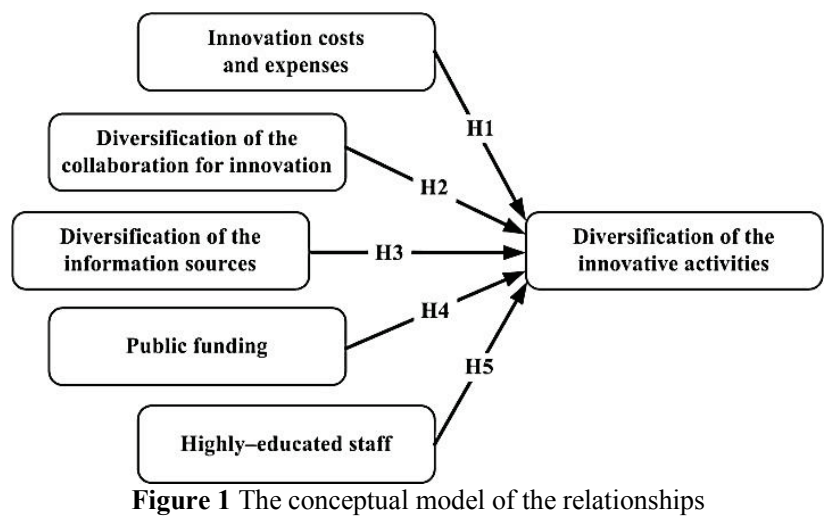

\section{METHODOLOGY}

The methodology is composed of four phases. Firstly, the valid and completed answers collected with CIS 2012 are selected. The analysis was restricted to units with observable innovation activities. In the second phase the variables from the CIS 2012 questionnaire that can be tested as potential factors for the innovation activities are selected. The selection is based on the data availability and the significance of the given variable in relation to the concept of diversification of innovation activities. In phase three the selected variables are justified with relevant literature and measuring model is proposed. And finally, in the last phase the proposed model is tested and the supported hypotheses are determined.

The CIS (Community Innovation Survey) was chosen as the empirical basis for our analyses because of its rich variable content and high response figures. The dataset that was used, CIS 2012, covered the years 2010-2012, and it was carried out during the year 2013. This is a firm level survey, conducted every 4 years in all EU states and some non-EU countries using a harmonized questionnaire. The questionnaire consists of 12 sections for collecting some general data and information relevant 
for the innovations in the respondents firms. Conducting the survey in Macedonia followed the procedure explained in the third edition of Oslo Manual. Detailed descriptive survey results for all countries and aggregate statistics are provided by Eurostat. The Macedonian sample is administered by the State Statistical Office of the Republic of Macedonia. The sample collected by CIS 2012 consists of 1130 surveyed companies. A profile of informants' firms is given in Tab. 1. The surveyed firms are distributed across all major sectors of economic activity in Macedonia. As shown, around $82 \%$ of the surveyed companies are small, $15 \%$ are medium and $3 \%$ are large corporations. Given the original CIS 2012 database, we have restricted the analysis to units with observable innovation activities. This selection produced final dataset of 194 responses.

The questions of interest for this study were answered only by the units with observable innovation activities; therefore the two stage Heckman procedure was not needed. The variables were transformed to five-point Likert scale and the hypothesized relationships between the variables were tested with multiple regression analysis. When using this methodology, one has to check the multicollinearity. Multicollinearity of the explanatory variables exists when the variables are correlated between themselves. Our model includes variables that belong to different categories, so the mutual correlation between the variables is minimized. Multicollinearity is tested using variance inflation factors (VIFs) to avoid the risk of suppressor effects in multiple regression analyses. VIF scores in all variables range between 1 and 1.2, which is well below the normally recommended cut-off score of 10 . The summary of the statistics and correlation matrix of the variables is reported in Tab. 2 .

Table 1 Demographic characteristics of the CIS 2012 dataset $(n=1130)$

\begin{tabular}{|c|c|c|}
\hline Characteristics & $\begin{array}{l}\text { Number } \\
\text { in sample }\end{array}$ & Percentage \\
\hline \multicolumn{3}{|l|}{ Industry } \\
\hline Agriculture, forestry and fishing & 38 & 3.36 \\
\hline Mining and quarrying & 31 & 2.74 \\
\hline Manufacturing & 414 & 36.64 \\
\hline $\begin{array}{l}\text { Electricity, gas, steam and air } \\
\text { conditioning supply }\end{array}$ & 9 & 0.80 \\
\hline $\begin{array}{l}\text { Water supply; sewerage, waste } \\
\text { management and remediation } \\
\text { activities }\end{array}$ & 55 & 4.87 \\
\hline Construction & 54 & 4.78 \\
\hline $\begin{array}{l}\text { Wholesale and retail trade; repair of } \\
\text { motor vehicles and motorcycles }\end{array}$ & 199 & 17.61 \\
\hline Accommodation and food activities & 79 & 6.99 \\
\hline Transportation and storage & 31 & 2.74 \\
\hline Information and communication & 43 & 3.81 \\
\hline Financial and insurance activities & 37 & 3.27 \\
\hline Real estate activities & 11 & 0.97 \\
\hline $\begin{array}{l}\text { Professional, scientific and technical } \\
\text { activities }\end{array}$ & 77 & 6.81 \\
\hline Administrative and support activities & 52 & 4.60 \\
\hline \multicolumn{3}{|l|}{ Firm size } \\
\hline Small & 475 & 42.87 \\
\hline Medium & 385 & 34.75 \\
\hline Large & 104 & 9.39 \\
\hline
\end{tabular}

Table 2 Descriptive statistics and correlations

\begin{tabular}{|c|c|c|c|c|c|}
\hline Variables & 1 & 2 & 3 & 4 & 5 \\
\hline 1. Innovation costs and expenses & 1.00 & & & & \\
\hline 2. Diversification of the collaboration for innovation & -0.097 & 1.00 & & & \\
\hline 3. Diversification of the information sources & -0.166 & -0.283 & 1.00 & & \\
\hline 4. Public funding for innovations & -0.080 & -0.016 & 0.00 & 1.00 & \\
\hline 5. Highly-educated staff & 0.065 & -0.051 & -0.099 & -0.021 & 1.00 \\
\hline Mean & 2.74 & 1.96 & 3.71 & 2.16 & 2.80 \\
\hline Standard deviation & 1.519 & 1.380 & 1.230 & 0.529 & 1.150 \\
\hline
\end{tabular}

\section{RESULTS AND DISCUSSION}

Tab. 3 presents the results of the regression analyses including the regression model coefficients with $t$ statistics and $p$-value. Below, the number of observations, $R^{2}$ (normal and adjusted) and $F$-statistics with $p$-value are presented. The beta coefficients represent factors' implicit importance weightings. The model supports three hypotheses. The innovation costs and expenses have positive effect on the diversification of the innovation activities in companies $(\beta=0.219, p<0.001)$. However, the access to public funding for innovations has no significant effect on the diversification of the innovation activities $(\beta=0.017, p>0.1)$. Both, the diversification of the collaboration for innovation and of the information sources, have positive effect on the diversification of the innovation activities $(\beta=0.247, p<0.001$ and $\beta=0.332$, $p<0.001$ respectively), while the share of highlyeducated staff has no significant effect on the examined output variable $(\beta=-0.043, p>0.1)$. In summary, these results provide considerable support for the hypotheses 1 , 2 and 3 and are statistically significant at 0.001 level.
In comparing our results with earlier research, we have found that they are mostly consistent with and further extend the relevant literature from the field. It was confirmed that greater diversification of the innovation activities is driven by allocation of sufficient resources for R\&D for innovations. This finding is supported, especially by the literature for product innovation [13]. On the other side, the diversification of the collaboration for innovation and of the information sources in companies are findings that are in line with the literature on open innovation and open collaboration principles [7, 12]. For instance, it is argued that the ability to exploit external knowledge is a critical component of innovative performance. Furthermore, firms that rely on collaborative strategies such as technology alliances to complement and supplement their internal innovation efforts, increase their internal innovation efforts and product innovation performance [33]. In addition, it is suggested in the literature that open innovation activities strengthen the positive effects of dynamic innovation capabilities on breakthrough innovation [34]. Also, the role of search for information in finding sources of variety 
for empowering organizations to create new combinations of technologies and knowledge is highlighted by the evolutionary economists [35]. Given these studies, our analyses contribute to the literature with an interesting and novel view of the nature of innovative activities in Macedonian enterprises.

Table 3 Results of the regression analyses

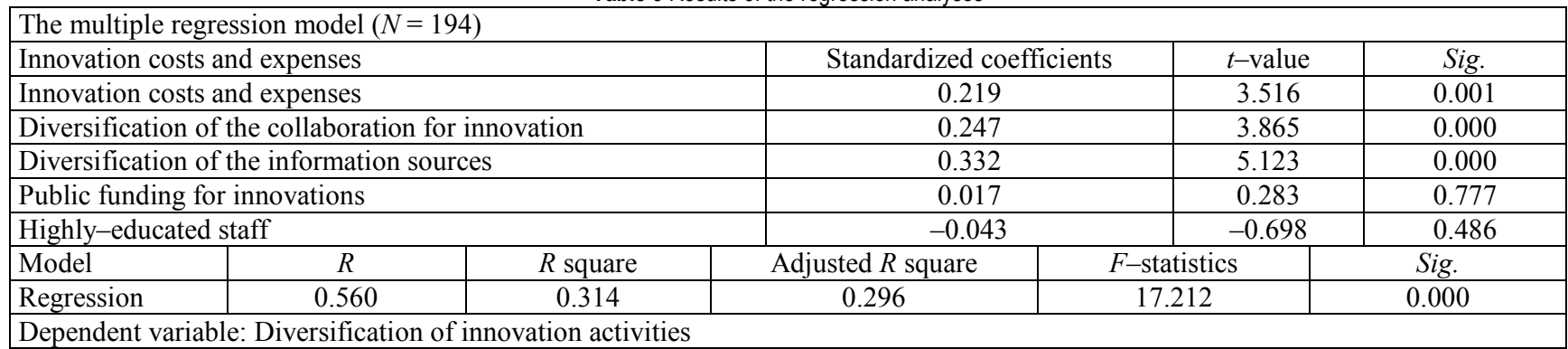

\section{CONCLUSION AND IMPLICATIONS}

The objective of this study was to investigate the innovativeness of Macedonian enterprises by analyzing the CIS database. The regression analysis confirmed that the variables selected from the CIS database are very important sources for increasing the variety of the innovative activities, and with that, accelerating the innovations in companies. In particular, the analyses that were employed to test the model relationships revealed that three of the proposed relationships are significantly supported by the results. The evaluation of the five hypotheses presented, provided insights for both managers, as well as researchers.

The findings of this study have several implications for the managers aiming to enhance company innovativeness as a vehicle for ensuring competitiveness and growth. The researched model of innovativeness of a firm suggests that more efforts should be put in extending the number of external collaborators and sources for information and knowledge for innovations. Also, greater variety in innovation activities could be achieved by further investment and allocation of enough resources in research and development. Therefore, the most important takeaway advice when deciding on the innovation activities for the managers is, not only to consider each of the innovation orientations (open and closed) separately, but also to take into account the combination of both, in order to decide on the balanced allocation of resources for internal and external innovation processes.

These findings contribute to the current research on firm's innovativeness in two important ways. First, these results complement the model of closed innovation by showing that innovativeness of a firm could be enhanced by investing in the internal innovation process. Second, the findings support the open innovation model by demonstrating the positive effects of engaging external collaborators and informative sources on firm innovativeness. In particular, greater variety of collaborative institutions increases the variety of innovation processes undertaken by the companies.

Although it advances the field and the literature, this study has several limitations which could be the subject of further research. Firstly, the analyses were done on the whole sample regardless of the firm size and industry. It is of interest that new research be conducted for testing the results for SMEs and for large corporations, as well as for specific industries. Secondly, the outcomes should be tested periodically, as new CIS is conducted, due to the continual socio-economic processes. Further research should explore the relevance of other internal and external factors for innovative activities of a firm. Also, future work should consider adopting a longitudinal design of the analyses to further test the causal relationship of the results. Lastly, the focus of this study was the context of Macedonian industrial sector. Therefore, further research should test the applicability of the proposed model for different countries where the CIS is conducted, by applying the methodology used in this study on the relevant CIS dataset.

\section{ACKNOWLEDGEMENTS}

The authors gratefully acknowledge the European Union (EuropeAid/136315/ID/ACT/MK).

\section{REFERENCES}

[1] Huggins, R. \& Strakova, L. (2012). Knowledge-based Economic Development in Emerging Regions: Policy Issues and Implications in the Balkan Peninsula. Regional Studies, 46(7), 961-975. https://doi.org/10.1080/00343404.2011.583912

[2] Polenakovik, R., Stankovska, I., \& Jovanovski, B. R. (2014). Macedonian National Innovation System - Main Challenges. Economic review: Journal of Economics and Business, 12(2), 21-34.

[3] Rubera, G. \& Kirca, A. H. (2012). Firm Innovativeness and Its Performance Outcomes: A Meta-Analytic Review and Theoretical Integration. Journal of Marketing, 76(3), 130147. https://doi.org/10.1509/jm.10.0494

[4] Mojsoska-Blazevski, N., Petreski, M., \& Petreska, D. (2015). Increasing the Labor Market Activity of the Poor, Females, and Informal Workers: Let's Make Work Pay in Macedonia. Eastern European Economics, 53(6), 466-490. https://doi.org/10.1080/00128775.2015.1103656

[5] Merikull, J. (2010). The Impact of Innovation on Employment. Eastern European Economics, 48(2), 25-38. https://doi.org/10.2753/EEE0012-8775480202

[6] Stankovska, I., Josimovski, S., \& Edwards, C. (2016). Digital channels diminish SME barriers: the case of the UK. Economic Research - Economska Istraživanja, 29(1), 217-232. https://doi.org/10.1080/1331677X.2016.1164926

[7] Chesbrough, H. (2003). Open Innovation. Harvard University Press, Cambridge, MA.

[8] Calantone, R. J., Chan, K., \& Cui, A. S. (2006). Decomposing Product Innovativeness and Its Effects on New Product Success. Journal of Product Innovation Management, 23(5), 408-421. 
https://doi.org/10.1111/j.1540-5885.2006.00213.x

[9] Subramanian, A. (1996). Innovativeness: Redefining the concept. Journal of Engineering and Technology Management, 13(3/4), 223-243. https://doi.org/10.1016/S0923-4748(96)01007-7

[10] Frenken, K., Van Oort, F., \& Verburg, T. (2007). Related variety, unrelated variety and regional economic growth. Regional Studies, 41(5), 685-697. https://doi.org/10.1080/00343400601120296

[11] Damanpour, F. \& Gopalakrishnan, S. (2001). The Dynamics of the Adoption of Product and Process Innovations in Organizations. Journal of Management Studies, 38(1), 45-65. https://doi.org/10.1111/1467-6486.00227

[12] Hashi, I. \& Stojcic, N. (2013). The impact of innovation activities on firm performance using a multi-stage model: Evidence from the Community Innovation Survey 4. Research Policy, 42(2), 353-366. https://doi.org/10.1016/j.respol.2012.09.011

[13] Bruijn, P. J. M. De. (2004). Mapping Innovation: Regional Dimensions of Innovation and Networking in the Netherlands. Tijdschrift voor Economische en Sociale Geografie, 95(4), 433-440. https://doi.org/10.1111/j.1467-9663.2004.00320.x

[14] Du, B. (2016). Social learning-based O2O model for innovative information diffusion. Technical Gazette, 23(2), 405-413. https://doi.org/10.17559/TV-20150314112123

[15] Escribano, A., Fosfuri, A., \& Tribo, J. A. (2009). Managing external knowledge flows: The moderating role of absorptive capacity. Research Policy, 38, 96-105. https://doi.org/10.1016/j.respol.2008.10.022

[16] Argyres, N. S. \& Silverman, B. S. (2004). R\&D, organization structure and the development of corporate technological knowledge. Strategic Management Journal, 25(8/9), 929-958. https://doi.org/10.1002/smj.387

[17] Leiponen, A. \& Helfat, C. E. (2011). Location, Decentralization and Knowledge Sources for Innovation. Organization Science, 22(3), 641-658. https://doi.org/10.1287/orsc.1100.0526

[18] Lundvall, B. \& Borras, S. (2005). Science, technology and innovation policy. Fagerberg, J., Mowery, D. C., \& Nelson, R. R. (Eds.) The Oxford handbook of innovation. Oxford University Press. Oxford, 599-631.

[19] Lerner, J. (1999). The government as venture capitalist: the long-run impact of the SBIR Program. Journal of Business, 72(3), 285-318. https://doi.org/10.1086/209616

[20] Hyytinen, A. \& Toivanen, O. (2005). Do financial constraints hold back innovation and growth? Evidence on the role of public policy. Research Policy, 34(9), 13851403. https://doi.org/10.1016/j.respol.2005.06.004

[21] Czarnitzki, D., Ebersberger, B., \& Fier, A. (2007). The relationship between R\&D collaboration, subsidies and R\&D performance: empirical evidence from Finland and Germany. Journal of Applied Econometrics, 22, 1347-1366. https://doi.org/10.1002/jae.992

[22] David, P., Hall, B., \& Toole, A. (2000). Is public R\&D a complement or substitute for private $\mathrm{R} \& \mathrm{D}$ ? A review of the econometric evidence. Research Policy, 29(4/5), 497-529. https://doi.org/10.1016/S0048-7333(99)00087-6

[23] Almus, M. \& Czarnitzki, D. (2003). The effects of public R\&D subsidies on firms' innovation activities: the case of Eastern Germany. Journal of Business \& Economic Statistics, 21(2), 226-236. https://doi.org/10.1198/073500103288618918

[24] Gonzalez, X. \& Pazo, C. (2008). Do public subsidies stimulate private R\&D spending? Research Policy, 37(3), 371-389. https://doi.org/10.1016/j.respol.2007.10.009

[25] Lach, S. (2002). Do R\&D subsidies stimulate or displace private $\mathrm{R} \& \mathrm{D}$ ? Evidence from Israel. The Journal of Industrial Economics, 50(4), 369-390. https://doi.org/10.1111/1467-6451.00182
[26] Ebersberger, B. (2011). Public funding for innovation and the exit of firms. Journal of Evolutionary Economics, 21(3), 519-543. https://doi.org/10.1007/s00191-010-0186-0

[27] Hall, B. H. (2002). The Financing of Research and Development. Oxford Review of Economic Policy, 18(1), 35-51. https://doi.org/10.1093/oxrep/18.1.35

[28] Fain, N., Kline, M., Vukasinovic, N., \& Duhovnik, J. (2010). The impact of management on creativity and knowledge transfer in an academic virtual enterprise. Technical Gazette, 17(3), 347-351.

[29] Santoro, M. D. \& Chakrabarti, A. K. (2002). Firm size and technology centrality in industry-university interactions. Research Policy, 31(11), 63-80. https://doi.org/10.1016/S0048-7333(01)00190-1

[30] Laursen, K. \& Salter, A. (2006). Open for Innovation: The Role of Openness in Explaining Innovation Performance among U.K. Manufacturing Firms. Strategic Management Journal, 27, 131-150. https://doi.org/10.1002/smj.507

[31] Crnjac Milic, D., Martinovic, G., \& Fercec, I. (2009). Elearning: situation and perspectives. Technical Gazette, 16(2), 31-36.

[32] Zahra, S. A. \& George, G. (2002). Absorptive capacity: a review, reconceptualization, and extension. Academy of Management Review, 27(2), 185-203. https://doi.org/10.5465/amr.2002.6587995

[33] Faems, D., de Visser, M., Andries, P., \& Van Looy, B. (2010). Technology Alliance Portfolios and Financial Performance: Value-Enhancing and Cost-Increasing Effects of Open Innovation. Journal of Product Innovation Management, 27(6), 785-796 https://doi.org/10.1111/j.1540-5885.2010.00752.x

[34] Cheng, C. C. J. \& Chen, J. (2013). Breakthrough innovation: the roles of dynamic innovation capabilities and open innovation activities. Journal of Business \& Industrial Marketing, 28(5), 444-454. https://doi.org/10.1108/08858621311330281

[35] Benedicic, J., Zavbi, R., \& Duhovnik, J. (2012). Development of a new method of searching a new product development opportunity. Technical Gazette, 19(4), 759767.

\section{Contact information:}

Radmil POLENAKOVIK, PhD, full professor Valentina GECEVSKA, PhD, full professor Bojan JOVANOVSKI, MSc, teaching assistan Trajce VELKOVSKI, MSc, teaching assistant University Ss. Cyril and Methodius Skopje, Faculty of Mechanical Engineering Karpos 2 bb, 1000 Skopje, Macedonia E-mail: radmil.polenakovik@mf.edu.mk E-mail: valentina.gecevska@mf.edu.mk E-mail: bojan.r.jovanovski@mf.edu.mk

E-mail: trajce.velkovski@mf.edu.mk

Ivana STANKOVSKA, PhD, project manager

National Centre for Development of Innovation and Entrepreneurial Learning Dame Gruev 1/2-17, 1000 Skopje, Macedonia

E-mail: ivana.stankovska@ncdiel.mk

Dragan SUTEVSKI, PhD, consultant

Sutevski Consulting

llindenska 19, 1300 Kumanovo, Macedonia

E-mail: dragan.sutevski@pretpriemac.com 